\title{
Mushroom cultivation: Substantial key to food security
}

\section{Vijay Vardhan Pandey*}

Forest Pathology Discipline, Forest Protection Division, Forest Research Institute, Dehradun (Uttarakhand), India

\section{Anuradha Kumari}

Forest Pathology Discipline, Forest Protection Division, Forest Research Institute, Dehradun (Uttarakhand), India

\section{Manoj Kumar}

Forest Pathology Discipline, Forest Protection Division, Forest Research Institute, Dehradun (Uttarakhand), India

\section{Jalaj Saxena}

Forest Pathology Discipline, Forest Protection Division, Forest Research Institute, Dehradun (Uttarakhand), India

Charul Kainthola

Forest Pathology Discipline, Forest Protection Division, Forest Research Institute, Dehradun (Uttarakhand), India

\section{Amit Pandey}

Forest Pathology Discipline, Forest Protection Division, Forest Research Institute, Dehradun (Uttarakhand), India

*Corresponding author. E-mail: vijayvardhan1989@gmail.com

\section{Article Info}

DOI:10.31018/jans.v10i4.1941 Received: November 6, 2018 Revised: November 25, 2018 Accepted: November 30, 2018

\section{How to Cite}

Pandey, V. V. et al. (2018). Mushroom cultivation: Substantial key to food security. Journal of Applied and Natural Science, 10(4): 1325-1331

\begin{abstract}
The worldwide sustenance and wholesome security of the expanding population is a generous test, which searches for new harvest (better yield from conventional ones) as a wellspring of nourishment sustenance and recoveries from malnutrition and food scarcity. Alluding to it, mushrooms discover some help which can be developed even via landless individuals, that too on decaying material and could be a source for proteinaceous sustenance. Metric huge amounts of natural waste and buildups are created every year which can possibly be reused as a substrate for mushroom cultivation. Mushroom cultivation being an indoor movement, requires less work and benefit adventure gives abundant chances to jobless.
\end{abstract}

Keywords: Edible mushroom cultivation, Food, Malnutrition, Population, Scarcity

\section{INTRODUCTION}

Food is one of the vital necessities of life. It provides energy for all vital activities of life. From ages, humanity is struggling with malnutrition and food scarcity because of poor agriculture production due to various factors. Growing population, urbanization and desertification making this problem more difficult. This situation is quite intense in African countries and developing Asian countries. In future, this situation will be more difficult to deal. Millions of people will have to face malnutrition and hunger or even worse. According to the report of Global Hunger Index 2017; African and Asian countries are facing a huge problem of hunger and malnutrition and among developing Asian nations; India is facing a "serious" hunger problem and it ranks $103^{\text {th }}$ out of the 119 countries on the global hunger index - behind Nepal, Bangladesh and Iraq but ahead of North Korea and Pakistan (Global Hunger Index, 2018) According to the Population reference bureau (2016), the world population estimated nearly 7.4 billion. In 2050 the world's population will reach an estimated 9.1 billion, which is 34 per cent higher than today. It will further increase to approx. 11.2 billion in the year 2100. India and China will be the major contributor in this projected population. The population of India is around 135 crores (World Population Review, 2018) India will become the world's most populous country by 2022 surpassing China and its population reaching 1.7 billion by 2050 (FAO, 2009). Urbanization will proceed at a accelerated pace and around two third of the total population will be urban (compared to approx 50 per cent today). Due to the rapid growth in urbanization, agricultural land sink and possibilities of land degradation and desertification is rising rapidly. According to FAO (2009) report, annual cereal and meat production must be raised to 
about 3 billion tons from 2.1 billion tons and 470 million tons from 200 million tons respectively in order to fulfill increase in demand of food production which can only be achieved through proper implementation of necessary investments and policies regarding agricultural production. Be that as it may, expanding production isn't the best way to accomplish nourishment security and sustenance. Strategies and projects ought to be intended to upgrade access by battling neediness, lack of healthy sustenance, particularly in provincial zones. It will likewise require arrangements that help ranchers and other private members in developing nations and urge them in horticulture to upgrade development in that division. In any case, the truth and certainty are that comprehensively the rate of development in yields of the major cereal crops has been consistently declining; it dropped from 3.2 percent in 1960 to 1.5 percent in 2000. Malnutrition can hold on in the midst of adequate supplies in view of lacking income opportunities for the poor and the non appearance of powerful social wellbeing nets. Experience of nations that have succeeded with regards to diminishing craving and malnutrition demonstrates that monetary development does not ensure guarantee achievement. Development in farming, especially in smallholder division is somewhere around twice as compelling in profiting the poorest as think about development from non-agribusiness areas. This isn't astonishing since 75 percent of the poor in developing nations live in country regions and their livelihoods are straightforwardly or in a roundabout way connected to agribusiness. According to the report of World Population review; last two decades have witnessed an increase in the number of Indians living in urban areas but $67 \%$ of Indians still live in rural areas (World Population Review, 2018).

To cure hunger and malnutrition, there should be solid efforts in the form of extensive social activities that includes food assistance, health and sanitation. Beside this promotion of education and training is also important. more efforts should be focused on deprived class. Most of the countries cannot grow all consumable. They will remain dependent on international trade to ensure food security. In 2008-09 it was estimated that by 2050 , net imports of developing countries will be doubled from 135 million metric tons to 300 million metric tons. In 2009, the UK government's chief scientific advisor, Professor John Beddington, warned that growing populations, falling energy reserves and food shortages would create a "perfect storm" of shortages of food, water, and energy by 2030 (The Guardian, 2009; The Guardian, 2011; Fine facts, 2009). According to a report by the United Nations Food and Agriculture Organisation (FAO, 2009), the world will have to produce $70 \%$ more food by 2050 to feed a project- ed extra 2.3 billion people (UNFAO, 2008). In the case of India, it would be predicted nearly 1.70 billion surpassing China (PopulationPyramid.net, 2018). A report commissioned by the agriculture ministry has called attention to that at the current rate of population and salary development, India will have to undoubtedly post a development of $4.2 \%$ every year in cereal production in the decade until 2020 rather than the under $2 \%$ it accomplished in the earlier decade. The investigation predicts that grain production would be 260 million tons by 2020 in continuation with a sensible ascent of half in the utilization of manures, development of water system and innovative progressions. It is to be noticed that the rate at which population is increasing along with the growth in prosperity, an exponential rise in demand for food grain will be witnessed which will require availability of a higher per capita. The increase in per capita income is supported by the fact that by 2020 , the annual per capita availability of cereals in India will rise to $215 \mathrm{~kg}$ per capita which was approximately $181 \mathrm{~kg}$ in 2001. As a result of urbanization, the demand for protein rich food such as eggs, meat and milk products is likely to increase four times in 2020 more than as it was in 1993. Again to increase these we have to increase cereals and oilseed production as these are consumed by cattle. There are many such factors that pose multiple issues that policymakers have to deal with (Deccan chronicle, 2018) .The observed figures for 2007 demonstrated a genuine increment in absolute numbers of undernourished individuals on the planet, with 923 million undernourished in 2007, versus 832 million of every 1995 (FAO, 2009). In 2009 FAO estimated a much more dramatic increment, to 1.02 billion.

Looking at all these scenarios there is a need to focus on other available food supplementary resources so that we can survive in that condition and protect masses from the malnutrition. One of the best resources we have, which can be supplementary to the cereals is Mushrooms. It is the most well-known and documented edible forest product (Chamberlain et al., 1998). Since old occasions, mushrooms were designated as "food of gods" by the Romans. The Greeks viewed them as giving solidarity to warriors in fights. Mushrooms are strange, social, customary and incredible (Arora and Shepard, 2008). Mushrooms have been widely used as foods (Falconer and Koppell, 1990; Gilbert and Robinson, 1957). It was prized as delicacy food by the Pharaohs (Daba et al., 2008). It is a valuable resource for medicines as well (Lakhanpal and Rana, 2005). Mushroom are source of multiple nutrients, fibers, phytochemical which provides various nutritional and health benefits (Cheung, 2010). Their medicinal values include wound-healing, immunity-enhancement, and tumour-retarding effects (Chang, 1999; Dai et al., 
Pandey, V. V. et al. / J. Appl. \& Nat. Sci. 10 (4): 1325-1331 (2018)

Table 1. Mushroom production in world and China's share. Source: FAOSTAT Data (2014).

\begin{tabular}{lccc}
\hline Year & $\begin{array}{c}\text { World } \\
\text { (In tons) }\end{array}$ & $\begin{array}{c}\text { China } \\
\text { (In tons) }\end{array}$ & $\begin{array}{c}\text { China/world } \\
\text { (\%) }\end{array}$ \\
\hline 2000 & 4205788 & 2400000 & 57.064 \\
2001 & 4530048 & 2660000 & 58.71 \\
2002 & 4729290 & 2850000 & 60.26 \\
2003 & 4921099 & 3000000 & 60.96 \\
2004 & 5276951 & 3350000 & 63.48 \\
2005 & 5299546 & 3400000 & 64.15 \\
2006 & 5559916 & 3675000 & 66.09 \\
2007 & 5990976 & 4060000 & 67.76 \\
2008 & 6823531 & 4702355 & 68.91 \\
2009 & 7212848 & 4672776 & 64.78 \\
2010 & 7398664 & 4826000 & 65.22 \\
2011 & 8406245 & 5658972 & 67.31 \\
2012 & 9592291 & 6527965 & 68.05 \\
2013 & 9762375 & 7068102 & 72.40 \\
2014 & 10378163 & 7626791 & 73.48 \\
\hline
\end{tabular}

Table 2. Mushroom production in China and India. Source: FAOSTAT Data 2014)

\begin{tabular}{cccc}
\hline Year & $\begin{array}{c}\text { China } \\
\text { (In tons) }\end{array}$ & $\begin{array}{c}\text { India } \\
\text { (In tons) }\end{array}$ & $\begin{array}{c}\text { India/China } \\
\text { (\%) }\end{array}$ \\
\hline 2000 & 2400000 & 24000 & 1.0 \\
2001 & 2660000 & 30000 & 1.12 \\
2002 & 2850000 & 40000 & 1.40 \\
2003 & 3000000 & 40000 & 1.33 \\
2004 & 3350000 & 40000 & 1.19 \\
2005 & 3400000 & 40000 & 1.17 \\
2006 & 3675000 & 35000 & 0.95 \\
2007 & 4060000 & 37000 & 0.91 \\
2008 & 4702355 & 37000 & 0.78 \\
2009 & 4672776 & 37000 & 0.79 \\
2010 & 4826000 & 40600 & 0.84 \\
2011 & 5658972 & 40600 & 0.71 \\
2012 & 6527965 & 30000 & 0.45 \\
2013 & 7068102 & 17000 & 0.24 \\
2014 & 7626791 & 28000 & 0.36 \\
\hline
\end{tabular}

2009). Mushrooms have also shown extraordinary results in trials for HIVIAIDS patients in Africa (Chang, 2006).

Edible mushrooms were only traditionally harvested in wild and were difficult to domesticate and cultivate. Collection from wild woodlands is still important in the world and particularly in southern Asia (Arora, 2008; Yang et al., 2008), and other developing countries (Fanzo et al., 2012). Although cultivation of some species has had a long history. The shiitake (Lentinula edodes) could be one of the earliest species to be cultivated. Cultivation of oyster mushrooms and shiitake has grown rapidly in recent decades (Arora and Shepard, 2008). As the number of wild mushrooms shrinks from both the degraded environment and natural resources, cultivated mushrooms would not only provide food security, but also sustainable and more nutritious diets (Vinceti et al., 2013).

Significance of mushroom in controlling food scarcity problem: Diversifying agriculture activities in areas of horticulture is important for provid-
Table 3. Mushroom production in India during 2016 (Source: Sharma et al., 2017).

\begin{tabular}{|c|c|}
\hline Mushrooms Species & $\begin{array}{l}\text { Total } \\
\text { (Production in metric } \\
\text { tons) }\end{array}$ \\
\hline $\begin{array}{l}\text { Agaricus bisporus } \\
\text { (Button Mushroom) }\end{array}$ & 94676 \\
\hline $\begin{array}{l}\text { Pleurotus ostreatus } \\
\text { (Oyster Mushroom) }\end{array}$ & 21272 \\
\hline $\begin{array}{l}\text { Calocybe indica (Milky } \\
\text { Mushroom) }\end{array}$ & 3184 \\
\hline Other mushrooms & 10650 \\
\hline Total Cultivation & 129782 \\
\hline
\end{tabular}

ing nutritionals security to our people. Mushroom is such a content which imparts diversification as well as help in addressing the problems of quality food, health and environment related issues. Recycling of agro-waste including agro-industrial waste, major area to contribute conservation of natural resource and increased productivity, can enhance income and impart higher level of sustainability by using this waste for mushroom production. On commercial scale, a vast quantity of agriculture forestry, industrial and house-hold waste can be bio-converted to nutritious food. Moreover, we get highest protein produce per unit area and time i.e. 100 times more than the conventional agriculture and animal husbandry through indoor cultivation of mushrooms in vertical space. Technological ascent in mushroom production has scope to fulfill the gap of food-shortage without any pressure on land.

China's success story of mushroom cultivation: China has set a great example of rural development driven by bioinnovation and technological development of mushroom business in rapid growth and market expension of where rural economic development and poverty alleviation was quite significant. It is also an example of recycle economy and sustainable agriculture and forestry. The last five decades have witnessed rapid growth in cultivated mushroom production. The world mushroom production has expanded around multiple times from 1969 to 2009. The most outstanding increments saw in China, USA, Netherlands, India and Vietnam (FAOSTAT, 2014; Table 4). The aggregate mushroom production has expanded from 60,000 tons with under 15 million USD in 1978 to 25.7 million tons with more than 13 billion USD in 2008 (China Mushroom Association, 2009), and 149 billion Yuan (24 billion USD) in 2011(Wu et al., 2013 ). A lot of worldwide mushroom production has expanded from $5.7 \%$ in 1978 to $80 \%$ in 2008 (China Mushroom Association, 2009; Wu et al., 2013). The mushroom business was positioned fifth among the farming results of China (Feng, 2009). The fares added up to 1.7 billion USD in 2008 (China Mushroom Association, 2009). In spite of the fact that China creates and shares a substantial level of the aggregate mushroom gen- 
Table 4. World production of mushrooms up to 2014 (Source: In tons FAOSTAT data on 8-19-2017).

\begin{tabular}{llll}
\hline Countries & $\mathbf{1 9 9 7}$ & $\mathbf{2 0 0 7}$ & $\mathbf{2 0 1 4}$ \\
\hline China & 1450000 & 4060000 & 7626791 \\
United states & $3,66,810$ & $3,59,630$ & 432100 \\
of America & & & \\
Netherlands & $2,40,000$ & $2,40,000$ & 310000 \\
Poland & 1,07207 & $1,40,000$ & 254224 \\
Spain & 81,304 & 1,31974 & 149854 \\
France & $1,73,000$ & 1,62450 & 108540 \\
Italy & 57,646 & 85,911 & 600114 \\
Ireland & 57,800 & 81,000 & 69600 \\
Canada & 68,020 & 73,260 & 102526 \\
United king- & $1,07,359$ & 71,500 & 94857 \\
dom & & & \\
Japan & 74,782 & 67,000 & 65,811 \\
Germany & 60,000 & 55,000 & 59923 \\
Indonesia & 19,000 & 48,247 & 37410 \\
India & 9,000 & 37000 & 28000 \\
Australia & 35,485 & 42,739 & 60023 \\
Korea & 13,181 & 28,764 & 27,130 \\
Iran & 12,601 & 28,000 & 80,239 \\
Hungary & 13,559 & 21,637 & 22,603 \\
Viet Nam & 12269 & 18,636 & 22,000 \\
Den mark & 8,766 & 11,000 & 10026 \\
Thai land & 9,000 & 8802 & 1000 \\
Israel & 1,260 & 9,500 & 10000 \\
South Africa & 7,406 & 10,320 & 17,299 \\
New Zealand & 7,500 & 8,500 & 607 \\
Switzerland & 7,239 & 7,440 & 8155 \\
Total World & 3101498 & 5990976 & 10378163 \\
Production & & & \\
\hline
\end{tabular}

eration of the world it sends out just $40 \%$ as rest is expended in the nation itself. (FAOSTAT 2014 data Table 1).

As labour- intensive agriculture, the mushroom industry created significant job opportunity. It was evaluated that around 25 million individuals worked in the mushroom cultivation and preparing industry (Hang et al., 2008). The customary mushroom generation locale was situated in southeast China where the atmosphere is warm and muggy and ideal for mushroom cultivation. Since the 1990s, the generation focus has been advancing toward the north where the work costs are lower, crude materials specific residuals of agribusiness are less expensive and bounteous, and showcase get to is nearer to more populated northern urban cities like Beijing and Tianjin. More recently the production has been moving to north eastern China and central China where woods and lands are more abundant and agriculture residues are more available.

The Chinese have recognized 966 edible mushrooms and 576 therapeutic types of which, around 70 species can be cultivated and 18 species can be cultivated industrially (Dai et al., 2009). China alone is now reported to grow more than 20 different types of mushroom at commercial scale and mushroom cultivation has become China sixth largest industry. China tops the world in growing Volvariella volvacea, Wolfiporia cocos

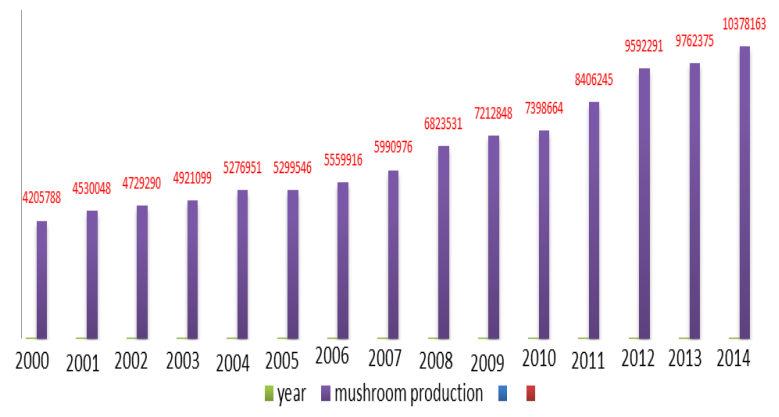

Fig. 1. Mushroom production (in tons) in the world up to 2014.

(Tuckahoe), Lentinula edodes (shiitake), Agaricus bisporus (agaric), Auricularia auricula-judae (wood ear), Auricularia polytricha (black fungus), Tremella fuciformis (white jelly fungus), Flammulina velutipes (eniki), Pleurotus ostreatus (oyster mushroom), Pleurotus eryngii (King trumpet mushroom) and Hericium erinaceus (hedgehog mushroom); Wu et al., (2013).

By and by, three geological regions- Europe, America and East Asia add to about $96 \%$ of world mushroom generation. With the ascent in salary level, the interest for mushrooms will undoubtedly increment in different parts of the world also. China has been cultivating mushrooms at low expenses with the assistance of occasional developing, state endowments and catching the potential markets on the planet with handled mushrooms at expenses not profitable to the cultivators in other mushroom developing nations. Mushroom farming today is being practiced in more than 100 nations and its production is expanding at a yearly rate of $6-7 \%$ (FAOSTAT, 2014). In some developed nations of Europe and America, mushroom cultivating has achieved the status of an innovative industry with elevated amounts of motorization and mechanization.

India status as Mushroom cultivation: prevalence of varied agro-climatic zones and abundance of farm waste enables different types of temperate, tropical and subtropical mushroom cultivation in India. It was assessed that India creates million tons of agrarian waste moreover, leafy foods buildup, coir husk, dried leaves, pruning's, coffee husk, tea waste which can possibly be reused as substrate for mushroom generation prompting nutritious sustenance and additionally natural excrement for harvests (Poppe, 2000). In India, there are major five mushroom species that cultivated commercially viz., Agaricus bisporus (white button mushroom), Pleurotus spp. (oyster), Volvariella volvacea (paddy straw mushroom), Calocybe indica (milky mushroom) and Lentinula edodes (shiitake). Even though cultivation technologies of many exotic species have been standardized, the markets are still dominated by button mushroom Agaricus bisporus, oysters Pleurotus spp. and Volvariella volvacea. All they contribute 
about $96 \%$ of the total mushroom produced in India. Milky mushroom (Calocybe indica) is an indigenous tropical mushroom of the country. In any case, its business development is for the most part to south Indian states just that contribute up to $3 \%$ to the aggregate mushroom production. Production of paddy straw mushroom become more popular in Chhattisgarh and Odisha and its production was registered at $7 \%$ to the total mushroom production. The short duration cultivation technology of many mushrooms has been standardized but still, mushrooms have so far not been exploited at commercial scale in India. Few of the growers in Uttarakhand and Himachal Pradesh have successfully cultivated mushrooms. However, the markets are dominating by the dried mushrooms imported from China and Taiwan. In North Eastern states, Uttarakhand and Chhattisgarh, mushroom cultivation is emerging as one of the leading industry (Kumar et al., 2017). In 2014 the total production of mushrooms in India was only 28000 tons (FAOSTAT, 2014 Table 2). Mushroom production in India is very low as compared to China. India was producing less than half per cent of mushroom (Table 2; FAOSTAT, 2014). It indicates that mushroom is not much popular and not a primary source of food. However, in forests, some ethnic communities use wild edible mushrooms as a food (Kumar et al., 2017; Borah et al., 2017; Devi, 2017; Semwal et al., 2014; Sarma et al., 2010; Harsh et al., 1993 and 1999). Commercial mushroom production is very uneven in the country. Though, this data does not contain the grower's lists that are not registered in any government agency.

Reasons for the slow progress of the mushroom industry in India: The retardation of progress is due to the following reasons:

- Non-availability of funds

- Poor harvest management and marketing

- No serious efforts to popularize edible mushrooms in spite of the abundant availability of raw materials, cheap labour force and suitability of agro-climatic conditions

- No serious efforts for collection and subsequent evaluation of locally available germplasm suitable for various agro-climatic conditions,

- Use of unpasteurized compost widely prevalent with small growers,

- No use/exploration of locally available substrates for compost,

- Unrefined pasteurization technique for compost and casing,

- Technology for successful cultivation of Oyster and Paddy straw Mushroom has not been properly standardized,

- Cheap production technology of edible mushrooms is lacking

- Lack of research with respect to the right stage of picking, grading and preservation.
Practical training is necessary to create the right environment as well as awareness to properly learn the art of mushroom growing. One of the major problems faced by the Indian farmers is a high mushroom training fee of mushroom research centres.

Marketing and exports: Popularly known as "vegetable meat", most edible mushrooms in market viz., Agaricus bisporus, whites, crimini and Portobello are safest to consume as they are commercially cultivated in controlled and aseptic environment in mushroom farms. List of species which are widely cultivated includes Hericium erinaceus (Lion's Mane Mushroom), Lentinula edodes (Shiitake Mushroom), Grifola frondosa (Maitake or hen of the woods Mushroom), Pleurotus and Flammulina velutipes (Enoki Mushroom) (Sharma et al., 2017, Table 3).

The nearby city is suitable for marketing of fresh mushrooms due to higher demands. It is mainly done in Delhi, Mumbai, Chennai, Chandigarh and others. Mushrooms are freeze-dried by the producer and exported at a good price. The retail price of fresh mushrooms in Indian markets ranges from Rs.50/- to Rs.100/- per kg, the price may change according to the season or special occasion. Due to market demand, fresh mushrooms are treated with potassium metabisulphite. Treatment makes them extra white and the casing adhering is also removed. For India, the export market is chiefly the USA, some quantities also exported to UAE, Russia, Netherlands, Germany, UK, Switzerland, Denmark, Israel, Sweden and other countries. India has no quota available from EU that is why Indian exporters have to sell processed mushrooms in the EU with additional taxes levied as per the laws of the EU, which makes it difficult for the Indian exporters to compete in the EU market (International Society for Mushroom Science, 2018).

Opportunities for mushroom production in India: Though India is not considered as major producer of any of the mushroom varieties but it cultivates edible and medicinal mushrooms due to its diverse climatic conditions. India has both technical and non-technical manpower necessary to carry out mushroom growing activities. Mushroom is cultivated on recycled agricultural residues which is accessible in nearly every part of the country. Black carbon emission from biomass burning is the second largest contributor to the current global warming (IPCC, 2014). At present, the territories with Rice-Wheat cropping arrangement of India is confronting an extreme test to deal with the mounting crop buildups. Mushroom cultivation can viably use these agro-deposits for generation of protein-rich nourishment and assumes a urgent job in the administration of these agro-buildups. The interest and supply hole in the worldwide exchange of mushrooms and the less- 
ening generation in western nations because of high work expenses would result in better market costs for Indian mushroom makers. With a population of more than 1.3 billion, India itself is a huge market for mushrooms. The development of rapid infrastructure facilities and well-organized distribution network provide the greater scope for marketing of perishable products in order to meet domestic consumer demands. In order to achieve success in domestic and export market, quality fresh mushrooms and mushroom fortified valueadded products needs to be produced at competitive rates not comprising of any agrochemical residues. Vermicompost, briquettes and organic manure etc. which can also be used as mushroom substrate, should be exploited for commercial utilization. India has a very good strategic geographical position which can help it to become a potential major mushroom producer as it will be fruitful in exporting the mushrooms to the Middle East, Southeast Asia and European countries.

Can mushroom help from food scarcity? A good example comes from Nigeria where people looking towards the mushroom and their production which will help them to fight with poverty, hunger and malnutrition (The Guardian, 2018). Researcher works on the low-cost development of mushroom technology. Mushrooms need a little space to grow and they have a high production rate in a given area when compared with agriculture crop. People benefitted with mushroom production and got livelihood to survive. Table 4 provides FAOSTAT DATA 2014 which shows the increase in production of mushroom from 1997 to 2014.

\section{Conclusion}

India has incredible potential in mushroom cultivation as India has immense assets which will be favorable in developing mushroom cultivation into a large scale industry. Technological advancement might enhance productivity and cost reduction; Marketing and related education of the technology is significantly important as well. The impact of mushroom cultivation on livelihoods and poverty reductions is significant and wide-spread. Mushroom cultivation requires very less land and resources and is suitable for farmers, women, children and self-help groups in the urban area. It is a high economic return venture. Mushroom cultivation also does not require a huge sum and can be started on a small scale. It can also be done on a part-time basis with little maintenance. Indirectly, mushroom cultivation is helpful in ameliorating the sustainability of marginal farmers through organic matter reprocessing, which primarily be used as growing substrate and at last carried back to the soil in the form of fertilizer. Forest floors and natural environment are likewise great spots to develop certain types of mushroom. Many mush- room species have not yet been examined; this can start new revelations of the medical advantages of mushrooms. Today, we have achieved food security by producing million tons of food grain with the variety of agricultural crops grown. However, struggle to achieve nutritional security is still under continuation. In anticipated future, expanding population, decreasing agrarian land, evolving condition, water shortage and desire for quality sustenance items at focused rates will be grave issue to be worried for. In this way, advancement of mushroom cultivation can end up being a stage to address dietary issues to decrease lack of healthy sustenance and giving vocation to landless poor.

\section{ACKNOWLEDGEMENTS}

The authors are grateful to the Director, Forest Research Institute, Dehradun for providing necessary facilities.

\section{REFERENCES}

1. Arora, D. (2008). Notes on Economic Mushrooms. Econ. Bot., 62, 540-544.

2. Arora, D. and Shepard, G.H. (2008). Mushrooms and Economic Botany 1. Econ. Bot., 62: 207-212.

3. Borah, N., RL Semwal and Garkoti, S.C. (2017). Ethnomycological knowledge of three indigenous communities of Assam, India. Indian Journal of Traditional Knowledge, 17(2): 327-335.

4. Chamberlain, J.; Bush, R. and Hammett, A. (1998). Non-Timber Forest Products: The Other Forest Products. For. Prod. J., 48: 10-19.

5. Chang, S.T. (2006). The world mushroom industry: Trends and technological development. Int. J. Med. Mushrooms, 8, 297-314.

6. Chang, S.T. (1999). World production of cultivated edible and medicinal mushrooms in 1997 with emphasis on Lentinus edodes in China. Int. J. Med. Mushrooms, 1: 291-300.

7. Chang, S.T.; Miles, P.G. (1992). Mushroom biologyA new discipline. Mycologist, 6: 64-65.

8. Cheung, P.C.K. (2010). The nutritional and health benefits of mushrooms. Nutr. Bull., 35, 292-299.

9. China Mushroom Association (2009). China Mushroom Statistical Yearbook; China's Statistic Publishing House: Beijing, China.

10.Daba, A.S.; Kabeil, S.; Botros, W.A. and El-Saadani, M. (2008). Production of mushroom (Pleurotus ostreatus) in Egypt as a source of nutritional and medicinal food. World J. Agric. Sci., 4: 630-634.

11.Dai, Y.C.; Yang, Z.L.; Cui, B.K.; Yu, C.J. and Zhou, L.W. (2009). Species diversity and utilization of medicinal mushrooms and fungi in China (Review). Int J. Med. Mushrooms, 11: 287-302.

12.Deccan Chronical (2018). 1.7 billion Indians by 2050: Much food for thought. https:// www.deccanchronicle.com/opinion/op-ed/310517/17 bn-indians-by-2050-much-food-for-thought.html Retrieved on 1-11-2018.

13.Devi, K. (2017). Ethnomycological Studies Of Some Wild Edible And Medicinal Mushrooms In Kamrup District Of Assam, India', International Journal of 
Current Advanced Research, 6(5): 3954-3959. DOI: http://dx.doi.org/10.24327/ijcar.2017.3959.0405

14.Falconer, J. and Koppell, C.R.S. (1990). The major significance of 'minor' forest products: The local use and value of forests in the West African humid forest zone. In FAO Community Forestry Note; Food and Agriculture Organization of the United Nations: Roma, Italy.

15.Fanzo, J.; Cogill, B. and Mattei, F. (2012). Metrics of sustainable diets and food systems. In Technical Brief-Madrid Roundtable; Bioversity International and Daniel and Nina Carasso Foundation: Rome, Italy.

16.FAO (2009). (Food and Agriculture Organization of the United Nations)One sixth of humanity undernourished - more than ever before". https:// www.sciencedaily.com/

releases/2009/06/090619121443.htm Retrieved on 1 $-11-2018$

17.FAOSTAT (2014). Available online: http:// faostat.fao.org/site/567/DesktopDefault.aspx? PagelD=567\#ancor (Retrieved on 1-11-2018).

18.Feng, J., (2009). Current status of edible mushroom sector in China. Mod. Agric., 2, 54-55.

19.Gilbert, F.A. and Robinson, R.F., 1957. Food from fungi. Economic Botany, 11, 126-145.

20.Global Hunger Index (2018) Global Hunger Index by Severity. http://www.globalhungerindex.org/results2018/ Retrieved on 20-11-2018.

21.Hang, S.; Su, C.; Fan, A. and Xu, S. (2008). Cultivation, utilization and development of edible fungi in China. Edible Fungi China, 27: 3-5.

22. Harsh N.S.K., Rai B.K. and Soni V.K. (1999). Some Ethnomycological Studies from Madhya Pradesh, India. In: Singh J., Aneja K.R. (eds) From Ethnomycology to Fungal Biotechnology. Springer, Boston, MA

23.Harsh, N.S.K., B.K. Rai and Ayachi, S.S. (1993). Forest fungi and tribal economy - a case study in Baiga tribe of Madhya Pradesh (India). Journal of Tropical Forestry, 9: 270-279.

24.IPCC (2014). Climate Change 2014: Mitigation of Climate Change. Contribution of Working Group III to the Fifth Assessment Report of the Intergovernmental Panel on Climate Change [Edenhofer, O., R. Pichs-Madruga, Y. Sokona, E. Farahani, S. Kadner, K. Seyboth, A. Adler, I. Baum, S. Brunner, P. Eickemeier, B. Kriemann, J. Savolainen, S. Schlömer, C. von Stechow, T. Zwickel and J.C. Minx (eds.)]. Cambridge University Press, Cambridge, United Kingdom and New York, NY, USA

25.Kumar, M., N.S.K. Harsh, R. Prasad and Pandey, V.V. (2017). An ethnomycological survey of Jaunsar, Chakrata, Dehradun, India. Journal of Threatened Taxa, 9(9): 10717-10725. http://doi.org/10.11609/ jott.3306.9.9.10717-10725

26.Kumar, Satish, V.P. Sharma, M. Shirur and Kamal, S. (2017). Status of milky mushroom (Calocybe indica) in India - A review. Mushroom Research, 26 (1): 21-39.

27.Lakhanpal, T.N. and Rana, M. (2005). Medicinal and nutraceutical genetic resources of mushrooms. Plant Genetic Resources, 3: 288-303.

28.Poppe J. (2000). Use of agricultural waste materials in the cultivation of mushrooms. Mushroom Science, 15(1): 3-22.

29.Population Reference Bureau (2016). PRB Projects World Population Rising 33 Percent by 2050 to Nearly 10 Billion. https://www.prb.org/2016-worldpopulation-data-sheet/ Retrieved on 01-11-2018

30.PopulationPyramid.net (2018). Population Pyramids of the world from 1950 to 2100. (https:// www.populationpyramid.net/india/2050/ Retrieved on 01-11-2018

31.Sarma, T C., Sarma, I and N. Patiri ( 2010). Wild edible mushrooms used by some ethnic tribes of Western Assam. The Bioscan: Special issue, 3: 613625.

32.Semwal, K.C., S.L. Stephenson, V.K. Bhatt and Bhatt, R.P. ( 2014). Edible mushrooms of the northwestern Himalaya, India: a study of indigenous knowledge, distribution and diversity. Mycosphere 5 (3): 440-461.

33.Sharma, V. P., Annepu, S.K., Gautam, Y., Singh, M. and Kamal, S. (2017). Status of mushroom production in India. Mushroom Research, 26 (2): 111-120.

34. The Guardian (2009). "World faces 'perfect storm' of problems by 2030 , chief scientist to warn" https:// www.theguardian.com/science/2009/mar/18/perfectstorm-john-beddington-energy-food-climate. Retrieved on 1-11-2018.

35.The Guardian (2011). "Paul Ehrlich, a prophet of global population doom who is gloomier than ever". https://www.theguardian.com/environment/2011/ oct/23/paul-ehrlich-global-collapse-warning Retrieved on 1-11-2018.

36. The Guardian (2018). Mushroom to end food security. https://guardian.ng/features/mushrooms-to-endfood-scarcity/ Retrieved on 01-11-2018.

37. The International Society for Mushroom Science (2018). The Indian Mushroom Industry. http:// www.isms.biz/articles/the-indian-mushroom-industry/ Retrieved on 1-11-2018

38.UNFAO (2018). United National Food and Agriculture Organization - Economic and Social Development Department, 2008. "The State of Food Insecurity in the World, 2008: High food prices and food security threats and opportunities". Retrieved on 01-11-2018.

39.UNFAOSTAT (2017). United Nations, Food and Agriculture Organization Statistics, 2011. http: // faostat.fao.org/default.aspx. Retrieved on 19-082017.

40.Vinceti, B.; Termote, C.; Ickowitz, A.; Powell, B.; Kehlenbeck, K. and Hunter, D., 2013. The contribution of forests and trees to sustainable diets. Sustainability, 5, 4797-4824.

41.World Population Review (2018). India Population 2018. http://worldpopulationreview.com/countries/ india-population/ Retrieved on 01-11-2018.

42.Wu, S.R.; Zhao, C.Y.; Hou, B.; Tai, L.M. and Gui, M.Y. (2013). Analysis on chinese edible fungus production area layout of nearly five years. Edible Fungi China, 1, 51-53.

43.Yang, X.; He, J.; Li, C.; Ma, J.; Yang, Y. and Xu, J. (2008). Matsutake trade in Yunnan Province, China: An overview. Economic Botany, 62, 269-277. 